\title{
A Rare Complication Following Breast Implant Surgery: Capsular Contracture with a Cutaneous Silicone Fistula after Breast Reconstruction with Silicone Gel Implants
}

\author{
Klaus-Jürgen Walgenbach ${ }^{a}$ Christiane Kuhl $^{b}$ Christian Rudlowski ${ }^{c}$ Martin Poelcher ${ }^{c}$ \\ Axel Sauerwald ${ }^{c}$ Gisela Walgenbach-Brünagel ${ }^{\mathrm{a}}$ Walther Kuhn $^{c}$ Michael Braun $^{\mathrm{c}}$ \\ aDivision of Plastic and Aesthetic Surgery, \\ bepartment of Radiology, \\ 'Department of Gynecology and Obstetrics, University Hospital Bonn, Germany
}

\section{Keywords}

Cutaneous silicone fistula - Capsular contracture .

Silicone breast implant $\cdot$ MRI

\section{Summary}

Background: We report the case of a 74-year-old female patient who presented at the Breast Care Centre with watery discharge from a fistula in the inframammary fold of the left breast. Case Report: The patient initially presented with watery discharge coming from the fistula, which later took on a more viscous consistency. She reported mild discomfort as well as mild erythema. Clinical examination and diagnostic approaches including magnetic resonance imaging (MRI) revealed a cutaneous silicone fistula as a rare complication following breast implant reconstruction. The condition was treated with excision of the fistula and bilateral implant removal. Conclusions: This case report documents a rare complication following breast reconstruction with implants, and is to our knowledge the first described MRI-detected cutaneous silicone fistula.

\section{Introduction}

Implant-based reconstruction still remains the most popular way of breast reconstruction. Nevertheless, certain complications such as capsular contracture regularly occur. These can be related to ruptured implants with exposure of the sur-

\author{
Schlüsselwörter \\ Silikongel-Haut-Fistel · Kapaselkontraktur · \\ Silikon-Brustimplantat · MRT
}

\section{Zusammenfassung}

Hintergrund: Wir berichten über eine 74-jährige Patientin, die sich im Brustzentrum mit einer wässrigen Absonderung aus einer Fistel in der Inframammärfalte der linken Brust vorstellte. Kasuistik: Die Patientin hatte sich zunächst mit einer wässrigen Sekretion aus der Fistel an der linken Brust vorgestellt, diese Sekretion nahm später eine viskösere Form an. Sie berichtete über leichte Beschwerden und eine leichte Rötung. Die klinische Untersuchung sowie die bildgebenden Verfahren inklusive einer Magnet-Resonanz-Tomographie( MRT) ergaben eine Haut-Silikon-Fistel als eine seltene Komplikation nach Brustimplantat-Rekonstruktion. Als Behandlung wurden eine Fistelexzision sowie die beidseitige Entfernung der Brustimplantate durchgeführt. Zusammenfassung: Diese Kasuistik dokumentiert eine seltene Komplikation nach Brustrekonstruktion mit Implantaten und stellt unseres Wissens den ersten beschriebenen Fall einer MR-detektierten siliko-kutanen Fistel dar.

rounding tissue to silicone gel. In this report, we present the extremely rare complication of a cutaneous silicone gel fistula associated with a capsular contracture.
Klaus J. Walgenbach MD, PhD

Division of Plastic and Aesthetic Surgery University of Bonn

Sigmund-Freud-Strasse 25, 53127 Bonn, Germany

Tel. +49 228 28711-250, Fax -489

klaus.walgenbach@ukb.uni-bonn.de 


\section{Case Report}

Patient

A 74-year-old female patient had undergone a bilateral prophylactic subcutaneous mastectomy for microcalcifications, followed by a bilateral implant breast reconstruction 28 years ago. She recovered well from the reconstruction and had no problems for about 23 years. About 4.5 years ago, she recognized a beginning hardening initially on the left breast and later on the right breast. Besides the increased hardening, she had no other symptoms and problems. The beginning capsular contracture did not bother her for several years; she did not see a surgeon about this problem. About 3 months before diagnosis and treatment, she discovered some discharge coming from a small cutaneous fistula on her left breast. The discharge was initially watery but took on a more viscous consistency about 2 months later. After the initial examinations and diagnostic tests, the patient was referred to our Breast Care Centre. Besides a type II diabetes, the patient was healthy and in good condition.

\section{Clinical Findings}

Upon inspection, we found a bilateral mildly deformed breast with implants slightly cranialised and compressed. In the left inframammary fold, a $4 \times 3 \times 2 \mathrm{~cm}$ bruised area with a central fistula was detected (fig. 1). Following mild pressure applied to the left breast, a viscous discharge coming from the fistula was exposed. There were no signs of acute infection, nevertheless the area around the bruise appeared inflamed. No enlarged lymph nodes were palpable. Standard blood tests were within the normal range.

\section{Sonography}

Upon sonography, the bruised area had an irregular structure with diffuse margins, and appeared hyporeflective. There were no signs of malignancy.

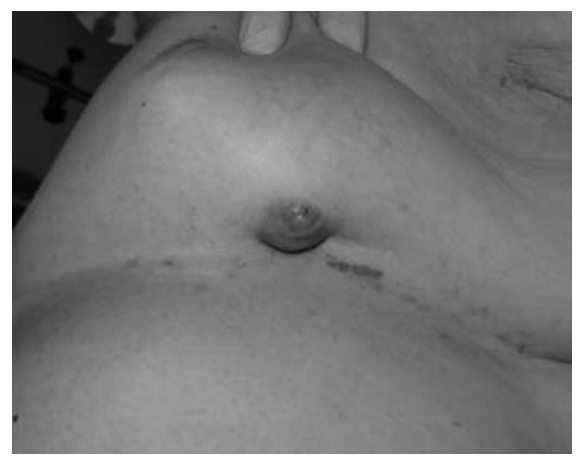

Fig. 1. Transcutaneous silicone fistula of the breast.

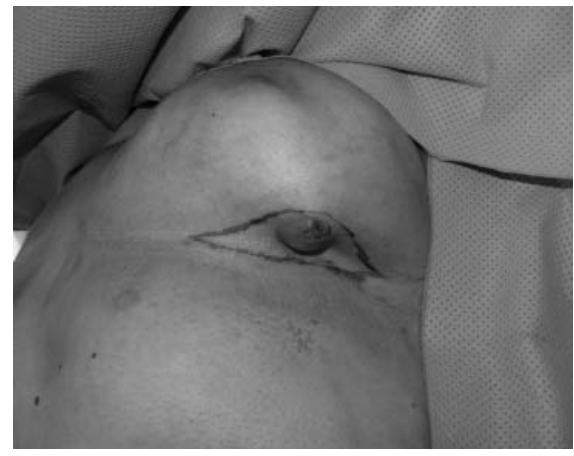

Fig. 3. Excisional pattern.
Magnetic Resonance Imaging

Upon magnetic resonance imaging (MRI), the right breast appeared completely normal, there were no specific findings, especially no signs of implant rupture or dislocation. Around the left implant, especially dorsally, larger quantities of a hypointense material, most likely representing silicone gel leaking from the prosthesis, were detected. The residues of the left implant appeared significantly smaller than the contralateral side. Following intravenous injection of contrast medium, an enhancement in the surrounding tissue was detected, compatible with an inflammatory reaction. No suspicious lymph nodes or malignancies were detected. In the lower part of the left breast, a fistula was clearly detectable. The fistula from the implant pocket to the external part of the inframammary fold was filled with the same hypointense material leaking from the prosthesis and representing silicone gel (fig. 2).

\section{Treatment}

The patient underwent surgery with excision of the cutaneous fistula in the left inframammary fold, followed by removal of both implants including the fibrous capsule (fig. 3). The patient did not wish further reconstruction or mastopexy. The implant pocket was irrigated extensively with high-pressure irrigation. The tissue was sent off for histological examination which confirmed the clinical findings (fig. 4).

\section{Discussion}

This case represents a rare complication following insertion of silicone gel breast implants. Only few similar cases are reported, either with development of a fistula [1] or without [2]. Many local and perioperative complications following breast

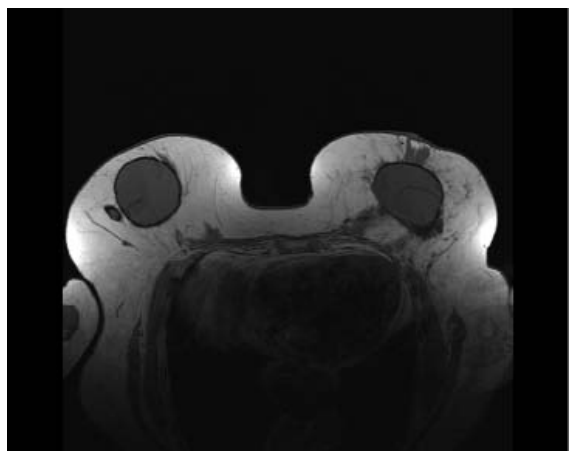

Fig. 2. MRI scan of cutaneous silicone fistula.

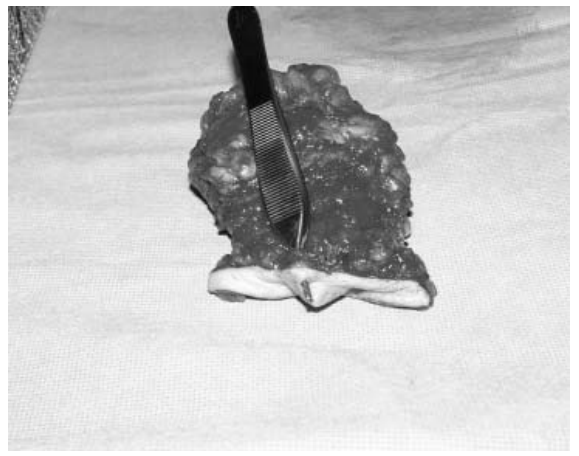

Fig. 4. Fistula from the implant pocket through to the inframammary fold. 
implant insertion have been described from the time before cohesive gel implants were available. They include fibrous contracture of the implant capsule; gel implant rupture (with or without migration of silicone gel outside the capsule) or saline implant deflation; shell folds or wrinkling; infection of the surgical wound or around the implant; hematoma; seroma; swelling of the breast; various skin rashes and other skin manifestations and epidermal proliferative reactions [3]; ulceration; necrosis of the skin, implant extrusion, misplacement, or displacement; silicone granuloma; axillary adenopathy; sensory loss and paresthesia; pain; abnormal lactation [4] and/or galactocele [5, 6]; thoracic skeletal asymmetries [7, 8]; pneumothorax [9]; and calcification; 'bleeding' or diffusion of small quantities of mostly lower-molecular-weight linear (and cyclic) silicone gel fluid compounds through the silicone elastomer shell.

In our patient, the medical history and clinical examination, especially the finding of viscous discharge, provided a clear diagnosis which was confirmed by ultrasound and MRI. However, these findings are very rare since it is very unusual that a fistula develops through the very firm and dense fibrous capsule that is formed during the process of capsular contracture. In contrast, the presence of silicone within the breast tissue after rupture of an implant is not uncommon. Only few reports describe silicone gel penetration into other spaces. In the worst scenario, silicone could protrude through the intercostal spaces resulting in exposure of the pleural space, causing most likely severe pleuritis. A similar case has been reported following bilateral replacement of implants and multiple closed capsulotomies several years subsequent to the original augmentation procedure. Silicone was detected in a pleural effusion, causing upper back pain due to pleuritic irritation [10]. Another unusual location is the intraductal extension of silicone detectable upon mammography. One case has been described with imaging features of silicone within the breast tissue and ducts that necessitated subcutaneous mastectomy as definitive treatment [11].

In our case, silicone penetrated through the subcutaneous tissue and skin via a cutaneous fistula. By definition, a fistula is a permanent abnormal passageway between two organs in the body or between an organ or cavity and the exterior of the body. Whether this fistula was initiated by a trauma or a tissue reaction to the silicone gel, remains unclear. In the past, a closed capsulotomy used to be a common procedure for the treatment of capsular contracture. Silicone rupture is a known complication of closed capsulotomy [11]. Increased pressure during this procedure could have been one reason for the development of unphysiological ducts within the tissue.

In the present case, the implants were inserted 28 years ago before cohesive gel implants were available, so most likely we will not see such a complication with the new generation of implants [12]. Nevertheless, locoregional silicone spread following cohesive gel silicone implant rupture has been already reported [13]. Awareness of such rare complications remains important. To our knowledge, this report describes the first MRI-detected and confirmed case of a cutaneous silicone fistula.

\section{Disclosure Statement}

The authors have no commercial interest in the subject of the study. There is no financial or material support.

\section{References}

1 Bertolin SM, Gonzalez R, Amorrortu J: Leakage of silicone gel through a cutaneous fistula. Plast Reconstr Surg 1994;93:1531-2.

2 Erdmann MW, Asplund O, Bahnasy N: Transcutaneous extravasation of silicone following breast augmentation Br J Plast Surg 1992;45:47980.

$>3$ Spiers EM, Grotting JC, Omura EF: An epidermal proliferative reaction associated with a silicone gel breast implant. Am J Dermatopathol 1994;16:3159

4 Hartley JH Jr, Schatten WE: Postoperative complication of lactation after augmentation mammaplasty. Plast Reconstr Surg 1971;47:150-3.

5 Deloach ED, Lord SA, Ruf LE: Unilateral galactocele following augmentation mammoplasty. Ann Plast Surg 1994;33:68-71.
6 Johnson PE, Hanson KD: Acute puerperal mastitis in the augmented breast. Plast Reconstr Surg 1996;98:723-5

7 Dickson MG, Sharpe DT: The complications of tissue expansion in breast reconstruction: a review of 75 cases. Br J Plast Surg 1987;40:629-35

$\checkmark$ Peters W, McEwan P: Capsular contracture simulating myocardial infarction on ECG. Plast Reconstr Surg 1993;91:529-32.

9 Brandt B, Breiting V, Christensen L, Nielsen M, Thomsen JL: Five years experience of breast augmentation using silicone gel prostheses with emphasis on capsule shrinkage. Scand J Plast Reconstr Surg 1984;18:311-6.
0 Hirmand H, Hoffman LA, Smith JP: Silicone migration to the pleural space associated with silicone-gel augmentation mammaplasty. Ann Plast Surg 1994;32:645-7.

11 Leibman AJ, Kossoff MB, Kruse BD: Intraductal extension of silicone from a ruptured breast implant. Plast Reconstr Surg 1992;89:546-7; comment in Plast Reconstr Surg 1993;92:176.

12 Brown MH, Shenker R, Silver SA: Cohesive silicone gel breast implants in aesthetic and reconstructive breast surgery. Plast Reconstr Surg 2005;116:768-79; discussion 780-1.

13 Lahiri A, Waters R: Locoregional silicone spread after high cohesive gel silicone implant rupture. J Plast Reconstr Aesthet Surg 2006;59:885-6. 